\title{
Effect of Preemergence Herbicides on Hybrid Bermudagrass Divot Resistance and Recovery
}

\author{
Patrick A. Jones, James T. Brosnan', Gregory K. Breeden, \\ José J. Vargas, Brandon J. Horvath, and John C. Sorochan \\ Department of Plant Sciences, University of Tennessee, 252 Ellington Plant \\ Science Building, 2431 Joe Johnson Drive, Knoxville, TN 37996
}

Additional index words. dithiopyr, hybrid bermudagrass $(C$. dactylon $\times$ C. transvaalensis $\mathrm{cv}$. Tifway), indaziflam, oxadiazon, prodiamine, pendimethalin

\begin{abstract}
Divoting is a common occurrence on golf courses and athletic fields. Research was conducted at the University of Tennessee Center for Athletic Field Safety (Knoxville, TN) during 2012-13 evaluating the effects of preemergence (PRE) herbicide applications on hybrid bermudagrass $[C$. dactylon (L.) Pers. $\times C$. transvaalensis Burtt-Davy, cv. Tifway] divot resistance and recovery. Plots were subjected to the factorial combination of seven herbicide treatments (indaziflam at 35 and $52.5 \mathrm{~g} \cdot \mathrm{ha}^{-1}$; prodiamine at 840

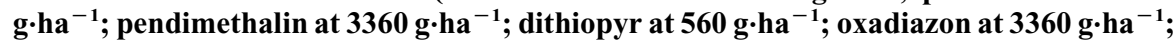
non-treated control) and three divot timings $[1,2$, and 3 months after herbicide treatment (MAT)]. Rates were based on label recommendations for preemergence crabgrass (Digitaria spp.) control. Herbicides were applied on 15 Mar. 2012 and 2013. Divots were generated using a weighted pendulum apparatus designed to impart $531 \mathrm{~J}$ of impact energy to the turf sward with a golf club. Divot resistance was quantified by measuring divot volume at each timing while divot recovery was quantified by measuring turf cover in the divot scar using digital image analysis. All herbicide-treated plots produced divots with volumes $\leq$ the non-treated control. In 2013, volumes were greater for divots produced 1 MAT $\left(215 \mathrm{~cm}^{3}\right)$ than those created 2 MAT $\left(191 \mathrm{~cm}^{3}\right)$ or 3 MAT $\left(157 \mathrm{~cm}^{3}\right)$. No differences in divot recovery were detected as a result of herbicide treatment in either year. Under the conditions of this study, applications of PRE herbicides at labeled rates did not affect divot resistance or recovery.

Chemical names: N-[(1R,2S)-2,3-dihydro-2,6-dimethyl-1H-inden-1-yl]-6-(1-fluoroethyl)1,3,5-triazine-2,4-diamine (indaziflam), 2,4 dinitro-N3,N3-dipropyl-6-(trifluoromethyl)1,3-benzenediamine (prodiamine), N-(1-ethylpropyl)-3,4-dimethyl-2,6-dinitrobenzenamine (pendimethalin), S,S-dimethyl 2-(difluoromethyl)-4-(2-methylpropyl)-6-(trifluoromethyl)3,5-pyridinedicarbothioate (dithiopyr), 3-[2,4-dichloro-5-(1-methylethoxy)phenyl]-5-(1, 1-dimethylethyl)-1,3,4-oxadiazol-2-(3H)-one (oxadiazon)
\end{abstract}

Hybrid bermudagrass [C. dactylon (L.) Pers. $\times$ C. transvaalensis Burtt-Davy] is commonly used on golf courses, athletic fields, and lawns throughout the transition zone and southward (McCarty and Miller, 2002). Hybrid bermudagrasses are frequently used on golf courses in place of common bermudagrass (Cynodon dactylon L.) in that they offer high turfgrass quality at low mowing heights in addition to being able to tolerate and quickly recover from traffic (McCarty and Miller, 2002; Thoms et al., 2011). According to Lyman et al. (2007), hectares of bermudagrass on U.S. golf courses (196,633 ha) exceed all other turf species.

\footnotetext{
Received for publication 22 July 2014. Accepted for publication 5 Sept. 2014.

We thank Doug Karcher for his assistance with statistical analysis. We also thank Daniel Farnsworth, Jake Huffer, Shane Breeden, and the Tennessee Agricultural Experiment Station for their assistance in this research.

${ }^{1}$ To whom reprint requests should be addressed; e-mail jbrosnan@utk.edu.
}

Divoting has been defined as a component of turfgrass wear stress that involves small pieces of turf being severed from soil by a golf club, cleated shoe, or animal hoof (Beard and Beard, 2005). Patton et al. (2010) estimated that 0.21 ha of turf is removed annually from bermudagrass golf course fairways in the United States. Bermudagrasses can vary in both divot resistance and divot recovery (Karcher et al., 2005; Trappe et al., 2011). Divot resistance is the ability of a turfgrass to resist divoting during impacts capable of displacing turf and soil (i.e., a golf club striking a ball), whereas divot recovery is the rate at which turf recovers (i.e., grows into the divot scar) after divots have been made (Karcher et al., 2005; Serensits, 2008).

Soil amendments have been shown to affect divot resistance in perennial ryegrass (Lolium perenne L.). McNitt and Landschoot (2005) amended sand root zones with several synthetic soil amendments [e.g., DuPont Shredded Carpet (Dupont, Wilmington, DE), Netlon (Netlon Ltd., Blackburn, England), Turfgrids (Synthetic Industries, Inc., Chattanooga, TN), etc.] before establishing 'SR 4200' perennial ryegrass. After establishment, divot resistance was quantified using PENNSWING, a weighted pendulum apparatus equipped with a pitching wedge. The researchers reported that soil amendments did not affect divot resistance on plots receiving minimal simulated traffic with the Brinkman Traffic Simulator. However, these amendments increased divot resistance (i.e., resulted in smaller divots) on plots receiving maximum simulated traffic. The researchers surmised that soil amendment effects were present on these plots as a result of reductions in turf cover after simulated traffic.

Serensits (2008) used the same device to quantify the effects of a plant growth regulator \{trinexapac-ethyl [4-(cyclopropyl- $(\alpha)$ hydroxymethylene)-3,5-dioxo-cyclohexane carboxylic acid ethyl ester]\} and vertical mowing on nine cultivars of kentucky bluegrass (Poa pratensis L.) and reported that divot length varied between cultivars with the shortest divots apparent in 'Limousine' and the longest in 'Penn State B'. Additionally, Serensits (2008) reported that trinexapac-ethyl application at $0.17 \mathrm{~kg} \cdot \mathrm{ha}^{-1}$ from May through July reduced divot length on all kentucky bluegrass cultivars relative to plots left nontreated. Serensits (2008) also found that divot resistance and turf shear strength were significantly correlated $(r=-0.40)$ to one another. A Turfgrass Shear Tester (Dr. Baden Clegg Pty Ltd., Jolimont, WA, Australia) was used by Trappe et al. (2011) to quantify force required to make a divot in various bermudagrass and zoysiagrass (Zoysia spp.) cultivars. The researchers reported that 'Patriot', 'Princess 77', Riviera', 'Tifsport', and 'Tifway' required 52 to $67 \mathrm{Nm}$ to generate a divot in July 2009. Conversely, 'Diamond' zoysiagrass required nearly twice the amount of energy to remove a divot $(115 \mathrm{Nm})$ on the same date.

Divot recovery has also been studied by several researchers. Steinke and Stier (2003) reported that nitrogen fertilizer along with monthly or bimonthly applications of the plant growth regulator trinexapac-ethyl $(0.05 \mathrm{~kg}$ a.i./ha) significantly improved turf quality, density, and chlorophyll levels of kentucky bluegrass; however, divot recovery was unaffected by either nitrogen or trinexapac-ethyl treatment. Karcher et al. (2005) evaluated divot recovery of 48 bermudagrass cultivars by subjecting each to a modified edger similar to Fry (2004); thus, all plots received divots of uniform volume. Recovery of each scar was monitored using digital image analysis. The researchers reported that the bermudagrass varieties 'La Ploma', 'Yukon', and 'SR 9554' exhibited the most rapid recovery, reaching $50 \%$ green coverage in $\approx 3.5 \mathrm{~d}$, whereas 'Tifsport', 'Patriot', and 'Ashmore' were the slowest to recover, taking an average of $6 \mathrm{~d}$ to reach $50 \%$ green cover.

Many of the PRE herbicides used to control annual weeds in bermudagrass turf have been shown to reduce bermudagrass root growth, including prodiamine, indaziflam, and dithiopyr (Jones et al., 2013; Tillman and Beard, 1997). Fishel and Coats (1993) reported that reductions in common bermudagrass root weights with PRE herbicides were greatest in 
the upper $5 \mathrm{~cm}$ of the soil profile. Reductions in root growth in this upper portion of a root zone could negatively impact divot resistance. Bermudagrass sod strength (commonly harvested to depths less than $5 \mathrm{~cm}$ ) has been shown to decline after PRE herbicide treatment (Sharpe et al., 1989). Moreover residual soil activity of PRE herbicides may negatively impact divot recovery from above-ground stolon growth. Boyd and Baird (1997) reported that prodiamine $\left(0.8 \mathrm{~kg} \cdot \mathrm{ha}^{-1}\right)$ and dithiopyr $\left(0.6 \mathrm{~kg} \cdot \mathrm{ha}^{-1}\right)$ applications at sprigging in Arkansas and Oklahoma reduced turf coverage $28 \mathrm{~d}$ after treatment compared with an untreated control. Similar responses were observed by McCarty and Weinbrecht (1997) in Florida 8 weeks after treatment with prodiamine and dithiopyr. Fagerness et al. (2002) observed similar responses in North Carolina and concluded that prodiamine $\left(1.1 \mathrm{~kg} \cdot \mathrm{ha}^{-1}\right)$ and dithiopyr $\left(0.6 \mathrm{~kg} \cdot \mathrm{ha}^{-1}\right)$ can significantly impede bermudagrass stolon growth from sprigs; however, when the researchers applied oxadiazon at $3.4 \mathrm{~kg} \cdot \mathrm{ha}^{-1}$, no significant reduction in percent cover was detected. Bingham and Hall (1985) observed similar responses with oxadiazon rates of 2.2 to 4.5 $\mathrm{kg} \cdot \mathrm{ha}^{-1}$. Oxadiazon is an inhibitor of protoporphyrinogen oxidase known to have a minimal effect on bermudagrass roots because the herbicide is absorbed primarily by foliar tissue of emerging shoots (Johnson, 1980; Senseman, 2007).

We hypothesize that reductions in root growth after PRE herbicide treatment could reduce divot resistance and recovery rates; however, PRE herbicide effects on hybrid bermudagrass divot resistance and recovery have received limited investigation. Given the frequency at which divots are generated on golf course turf, information of this nature would benefit turf managers controlling annual weeds on golf courses with PRE herbicides. Thus, the objective of this study was to determine the effects of several PRE herbicides on hybrid bermudagrass divot resistance and recovery.

\section{Materials and Methods}

Research was conducted during 2012 and 2013 at the University of Tennessee Center for Athletic Field Safety (Knoxville, TN) on a mature stand of weed-free 'Tifway' hybrid bermudagrass that was established from sprigs in May 2011. The root zone was a blend of $80 \%$ sand and $20 \%$ sphagnum peatmoss (by volume) that conformed to the particle size distribution and physical property specifications outlined by the U.S. Golf Association (USGA, 2007). Turf was maintained at a 3.2-cm height of cut with a reel mower three times weekly; clippings were returned to the surface after mowing. Irrigation was applied to maximize vigor and nutrients were applied at a rate $244 \mathrm{~kg}$ nitrogen/ha per year from a complete fertilizer $(24 \mathrm{~N}-2.6 \mathrm{P}-10 \mathrm{~K})$.

PRE herbicide treatments were applied to plots $(0.9 \mathrm{~m} \times 0.9 \mathrm{~m})$ on 15 Mar. 2012 and 2013 with a $\mathrm{CO}_{2}$-pressurized boom sprayer calibrated to deliver $281 \mathrm{~L} \cdot \mathrm{ha}^{-1}$ using 8002 flat-fan nozzles (Tee Jet; Spraying Systems Co., Roswell, GA). Treatments included indaziflam (Specticle 20WSP; Bayer Environmental Sciences, Research Triangle Park, $\mathrm{NC}$ ) at 35 and $52.5 \mathrm{~g} \cdot \mathrm{ha}^{-1}$, prodiamine (Barricade 65WG; Syngenta Crop Protection, Greensboro, NC) at $840 \mathrm{~g} \cdot \mathrm{ha}^{-1}$, pendimethalin (Pendulum 3.3EC; BASF Corporation, Research Triangle Park, NC) at $3360 \mathrm{~g} \cdot \mathrm{ha}^{-1}$, dithiopyr (Dimension 40WP; Dow AgroSciences LLC, Indianapolis, IN) at $560 \mathrm{~g} \cdot \mathrm{ha}^{-1}$, and oxadiazon (Ronstar 50WSP; Bayer Environmental Sciences) at $3360 \mathrm{~g} \cdot \mathrm{ha}^{-1}$ along with a non-treated control. All herbicide rates were selected according to label recommendations for preemergence crabgrass (Digitaria spp.) control in bermudagrass. All treatments received $\approx 6.4 \mathrm{~mm}$ of irrigation within $24 \mathrm{~h}$ of application.

Divots were generated using the DIVOT apparatus described by Brosnan et al. (2013). DIVOT consists of a structural frame, a pendulum-based reinforced shaft, and a leveling system that positions a golf club head above the turf surface. The shaft is released from a set height of $1.47 \mathrm{~m}$ above the turf surface and can be equipped with removable ballast masses to generate divots using varying levels of impact energy (Brosnan et al., 2013). During this experiment, the shaft was weighted to generate divots using $531 \mathrm{~J}$ of impact energy within the range tested by Brosnan et al. (2013) in previous experiments on kentucky bluegrass. A total of three divots per plot were generated 1, 2, and 3 MAT.
Divot resistance was quantified by measuring divot volume using methods similar to Trappe et al. (2011). Each divot scar was filled with a dried mixture of silica sand and sphagnum peatmoss $(80 \%$ sand: $20 \%$ peat by volume) having a bulk density of 1.51 $\mathrm{g} \cdot \mathrm{cm}^{-3}$. Divot volume was then calculated using Eq. [1]:

$$
\begin{aligned}
& \text { divot volume }\left(\mathrm{cm}^{3}\right) \\
& =\text { weight of sand to fill the divot scar }(\mathrm{g}) \\
& \quad * 1 \mathrm{~cm}^{3} / 1.51 \mathrm{~g}
\end{aligned}
$$

Divot recovery was measured biweekly using methods similar to Karcher et al. (2005). Digital images of each divot scar were collected using a light box constructed out of a polyethylene container (Rubbermaid Roughneck; Rubbermaid Commercial Products LLC, Winchester, VA) and four light-emitting diode lights (Sylvania LED 3-Button Silver Round Dragon Light Puck; OSRAM SYLVANIA, Danvers, MA). An interior blue frame with a $12.7 \times 31.7-\mathrm{cm}$ opening was placed around each divot scar to capture a uniform area of turf in each digital image (Fig. 1). Images were then analyzed for percent turf cover according to the methods of Karcher and Richardson (2005). Divot recovery was calculated using Eq. [2]:

$$
\begin{aligned}
\% \text { recovery }= & \left(\% \operatorname{cover}_{(\mathrm{x})}-\% \operatorname{cover}_{(0)} /\right. \\
& \left(100 \%-\% \operatorname{cover}_{(0)}\right)
\end{aligned}
$$

where $\% \operatorname{cover}_{(\mathrm{x})}$ is the percent green cover within the picture frame on the day the image was taken and $\% \operatorname{cover}_{(o)}$ is the percent green cover within the picture frame on the day of divot generation similar to Karcher et al. (2005).

Treatments were arranged in a seven $x$ three factorial, randomized complete block design with four replications. Factors include seven herbicide treatments and three divot timings $(1,2$, or 3 MAT). Divot volume data were subjected to analysis of variance in SAS (SAS Institute, Inc., Cary, NC) with Fisher's protected least significant difference test used to separate treatment means at $P \leq 0.05$.

Divot recovery data were analyzed using a one-phase exponential association non-linear

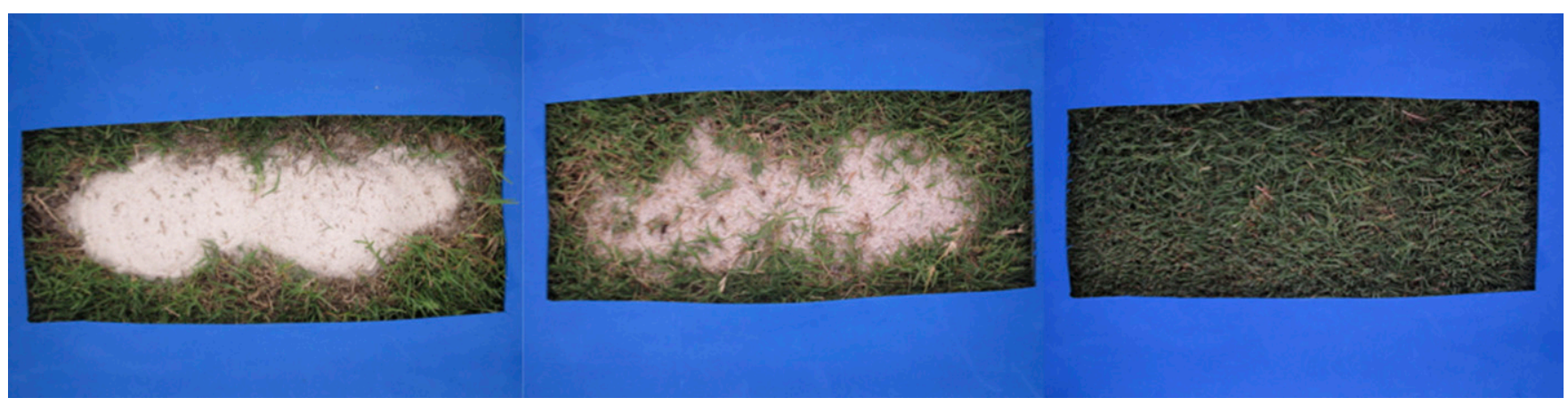

Fig. 1. Frame used to analyze digital images of divot scars generated on hybrid bermudagrass [C. dactylon (L.) Pers. $\times$ C. transvaalensis Burtt-Davey, cv. Tifway] 1, 2, and 3 months after applying seven preemergence herbicide treatments at the University of Tennessee Center for Athletic Field Safety (Knoxville, TN) in 2012 and 2013. Image on the left was captured the day of divoting; the image in the center represents $\approx 50 \%$ recovery; the image on the right represents $100 \%$ recovery. 
regression model [Eq. 3] in GraphPad Prism 6 for Mac OS X (GraphPad Software, San Diego, CA) similar to Karcher et al. (2005).

$$
\% \text { recovery }=1-\exp (-\mathrm{K} * \mathrm{DAI})
$$

Using this model, recovery increases asymptomatically until reaching $100 \% \mathrm{~K}$ is an estimated model parameter such that recovery equals $50 \%$ when days after divot injury equals $(0.6932 / \mathrm{K})$ (Motulsky and Christopoulos, 2003). Higher values of $\mathrm{K}$ indicate a faster recovery from divoting (Karcher et al., 2005). A sum-of-squares reduction F-test was used to determine if herbicide treatment affected divot recovery at each timing. This test compared the sum-of-squares from a global model where all herbicide treatments shared a $\mathrm{K}$ value (i.e., all herbicide treatments recovered at the same rate) against the cumulative sums of squares from models where $\mathrm{K}$ values were determined separately for each treatment.

\section{Results and Discussion}

Divot volume. Significant year-by-herbicide and year-by-divot timing interactions were detected in divot volume data. Therefore, data from each year were analyzed and presented separately. Within each year, no significant divot timing-by-herbicide interactions were detected in divot volume data allowing divot timing and herbicide effects on divot volume to be discussed individually.

Divot volume did not vary as a result of divot timing or herbicide in 2012; however, significant differences were detected among these factors in 2013 (Table 1). Differences in divot volume were detected among herbicide treatments; however, no herbicide produced divots significantly larger in volume than the non-treated control (Table 1). Divots created 1 and 2 MAT in 2013 were larger in volume $\left(191\right.$ to $\left.215 \mathrm{~cm}^{3}\right)$ than those created 3 MAT $\left(157 \mathrm{~cm}^{3}\right)$ as well. Reduced volume 3 MAT may be related to the fact that growing conditions when these divots were made were more favorable for active hybrid bermudagrass growth (Table 2). Active growth during this time period may lead to greater divot resistance and thus smaller volumes.

Trappe et al. (2011) measured the volume of divots created by two golfers swinging pitching wedges rather than with a mechanical instrument (i.e., PENNSWING, DIVOT, etc.) and reported bermudagrass divot volumes ranging from only 46 to $64 \mathrm{~cm}^{3}$. In the current study, individual divot volumes ranged from 150 to $222 \mathrm{~cm}^{3}$. Larger divot volume values may be related to differences in soil type between experiments as Trappe et al. (2011) quantified bermudagrass divot resistance on a Captina silt-loam soil (fine-silty mixed mesic Typic Fragiudalt), whereas our data were generated using bermudagrass established on a blend of $80 \%$ sand and $20 \%$ sphagnum peatmoss that conformed to USGA particle size distribution and physical property specifications. In a study exploring root zone effects on kentucky bluegrass divot resistance,
Brosnan et al. (2013) reported that divot length, width, and volume were greater on engineered sand root zones compared with silt loam. Differences between studies could be associated with the use of a mechanical instrument (e.g., DIVOT apparatus) to create divots compared with actual golfers. Divot length $(27 \mathrm{~cm})$ and width $(9 \mathrm{~cm})$ values averaged over all herbicide treatments in the current study are similar to untreated control values (i.e., no trinexapac-ethyl application) reported by Serensits (2008) using PENNSWING (a weighted pendulum device similar to that used here) to simulate divots made by football players' cleats on kentucky bluegrass established on a similar sand-based root zone to that used here.

Divot recovery. No significant differences in divot recovery were detected among herbicide treatments for divots generated 1,2 , or 3 MAT in either year (Fig. 2; Table 3). For each divot timing, sum-of-squares reduction F-tests indicated that all herbicide treatments shared a $\mathrm{K}$ value (i.e., all herbicide treatments recovered at the same rate) (Table 2 ). K values ranged from 0.019 to 0.049 and 0.035 to 0.043 in 2012 and 2013, respectively. $\mathrm{K}$ values were lower for divots generated 1 MAT than those made 2 and 3 MAT each year. Considering that higher $\mathrm{K}$ values are indicative of a faster divot recovery rate, we hypothesize that higher $\mathrm{K}$ values for divots generated 2 and 3 MAT were likely an effect of increased air temperature. Maximum/minimum air temperatures when recovery data were collected on divots generated 2 and 3 MAT averaged $30 / 16$ and $31 / 19{ }^{\circ} \mathrm{C}$, respectively, over the 2 years this study was conducted (Table 2). Comparatively, air temperatures averaged $26 / 12{ }^{\circ} \mathrm{C}$ when monitoring recovery of divots generated 1 MAT (Table 2). McCarty and Miller (2002) report that optimal air temperatures for bermudagrass growth range from 29 to $38^{\circ} \mathrm{C}$. Thus, increased air temperatures during the recovery period likely facilitated faster recovery rates for divots collected 2 and 3 MAT compared with those generated 1 MAT.

Lack of differences in divot recovery resulting from herbicide treatment may be related to hybrid bermudagrass recovery from below-ground rhizomes rather than stolons. Brosnan et al. (2011) reported no differences in 'Tifway' hybrid bermudagrass traffic tolerance or recovery resulting from PRE herbicide treatment and suggested that this was attributable to hybrid bermudagrass recovery from traffic stress through below-ground rhizome growth. The researchers also surmised that applied PRE

Table 1. Effects of divot timing and herbicide on divot volume of hybrid bermudagrass [C. dactylon (L.) Pers. $\times$ C. transvaalensis Burtt-Davey, cv. Tifway] at the University of Tennessee Center for Athletic Field Safety (Knoxville, TN) during 2012 and 2013.

\begin{tabular}{|c|c|c|c|}
\hline \multirow[b]{3}{*}{ Herbicide } & \multirow{3}{*}{$\begin{array}{c}\text { Rate } \\
\left(\mathrm{g} \cdot \mathrm{ha}^{-1}\right)\end{array}$} & \multicolumn{2}{|c|}{ Divot volume $^{z}$} \\
\hline & & ${ }^{n} 12$ & 2013 \\
\hline & & \multicolumn{2}{|c|}{ - } \\
\hline Dithiopyr & 560 & 184 & 163 \\
\hline Indaziflam & 35 & 201 & 172 \\
\hline Indaziflam & 52.5 & 184 & 186 \\
\hline Oxadiazon & 3360 & 166 & 191 \\
\hline Pendimethalin & 3360 & 160 & 168 \\
\hline Prodiamine & 840 & 162 & 222 \\
\hline Non-treated control & - & 150 & 214 \\
\hline $\mathrm{LSD}_{0.05}$ & & NS & 31 \\
\hline \multicolumn{4}{|l|}{ Divot timing ${ }^{y}$} \\
\hline $1 \mathrm{MAT}$ & & 166 & 215 \\
\hline 2 MAT & & 172 & 191 \\
\hline 3 MAT & & 180 & 157 \\
\hline $\operatorname{LSD}_{0.05}$ & & NS & 20 \\
\hline
\end{tabular}

${ }^{2}$ Divots were filled with a dried mixture of silica sand and sphagnum peatmoss ( $80 \%$ sand:20\% peat by volume) having a bulk density of $1.51 \mathrm{~g} \cdot \mathrm{cm}^{-3}$. Divot volume was calculated using the equation: divot volume $\left(\mathrm{cm}^{3}\right)=$ weight of sand to fill the divot scar $(\mathrm{g}) * 1 \mathrm{~cm}^{3} / 1.51 \mathrm{~g}$.

y Divots were created 1, 2, or 3 months after herbicide treatment (MAT) on 15 Mar. 2012 and 2013. Divots were generated using a weighted pendulum apparatus that generated $531 \mathrm{~J}$ of impact energy. Measurements were made using three divots per plot.

$\mathrm{LSD}=$ least significant difference.

Table 2. Environmental conditions during divot recovery periods in 2012 and 2013 at the University of Tennessee Center for Athletic Field Safety (Knoxville, TN).

\begin{tabular}{|c|c|c|c|c|c|c|}
\hline \multirow[b]{3}{*}{ Divot timing } & \multicolumn{3}{|c|}{2012} & \multicolumn{3}{|c|}{2013} \\
\hline & $\begin{array}{l}\text { Avg daily } \\
\text { maximum air } \\
\text { temperature }\end{array}$ & $\begin{array}{l}\text { Avg daily } \\
\text { minimum air } \\
\text { temperature }\end{array}$ & Rainfall & $\begin{array}{l}\text { Avg daily } \\
\text { maximum air } \\
\text { temperature }\end{array}$ & $\begin{array}{l}\text { Avg daily } \\
\text { minimum air } \\
\text { temperature }\end{array}$ & Rainfall \\
\hline & \multicolumn{2}{|c|}{------------- $\left({ }^{\circ} \mathrm{C}\right)-----------$} & $(\mathrm{mm})$ & \multicolumn{2}{|c|}{------------- $\left({ }^{\circ} \mathrm{C}\right)-----------$} & $(\mathrm{mm})$ \\
\hline $1 \mathrm{MAT}$ & 27 & 13 & 83 & 25 & 11 & 71 \\
\hline 2 MAT & 31 & 16 & 32 & 29 & 16 & 71 \\
\hline 3 MAT & 33 & 19 & 48 & 30 & 19 & 50 \\
\hline
\end{tabular}

MAT $=$ months after herbicide treatment. 


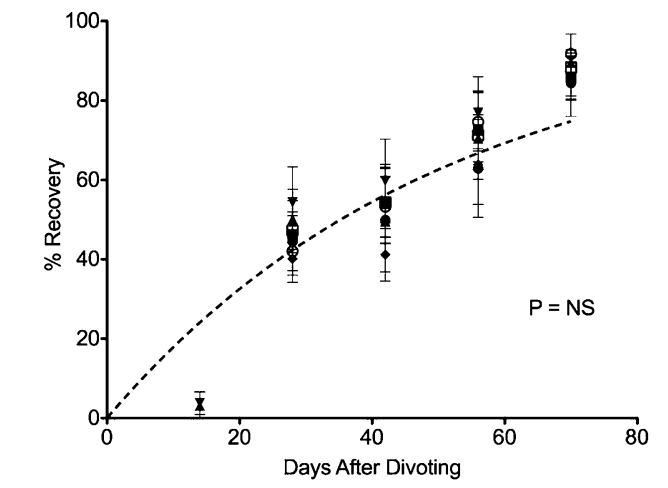

- Dithiopyr $(0.56 \mathrm{~kg})$

- Oxadiazon $(3.36 \mathrm{~kg})$

○ Pendimethalin $(3.36 \mathrm{~kg})$
\ Indaziflam $(35 \mathrm{~g})$

v Indaziflam $(52.5 \mathrm{~g})$

$\square$ Prodiamine $(840 \mathrm{~g})$

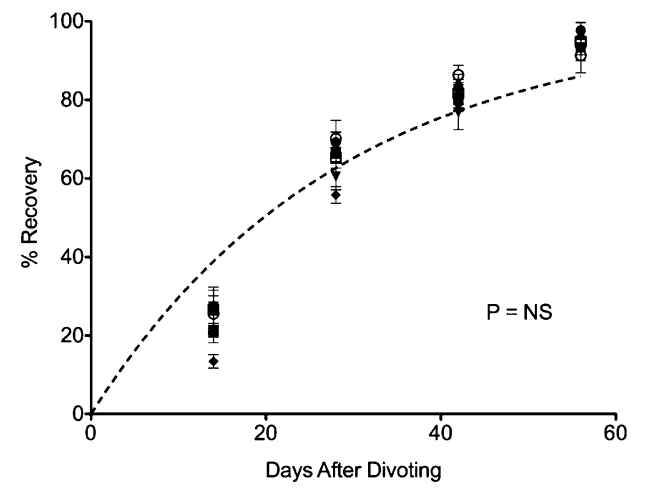

- Dithiopyr $(0.56 \mathrm{~kg})$

- Oxadiazon $(3.36 \mathrm{~kg})$

A Indaziflam (35 g)

- Indaziflam (52.5 g)

o Pendimethalin $(3.36 \mathrm{~kg})$

\section{MAT}
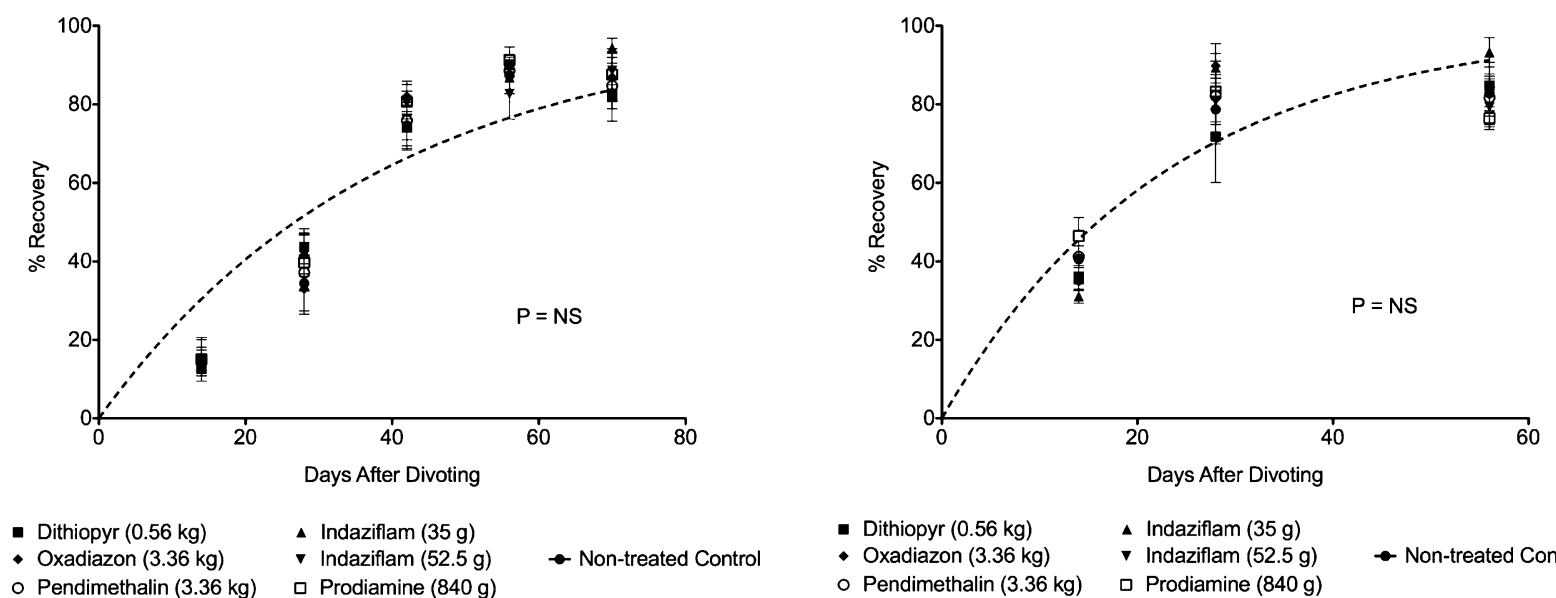

- Dithiopyr $(0.56 \mathrm{~kg})$ ॥ Indaziflam $(35 \mathrm{~g})$

- Oxadiazon $(3.36 \mathrm{~kg}) \quad \boldsymbol{V}$ Indaziflam $(52.5 \mathrm{~g})$

○ Pendimethalin $(3.36 \mathrm{~kg}) \quad \square$ Prodiamine $(840 \mathrm{~g})$

- Non-treated Control

\section{MAT}

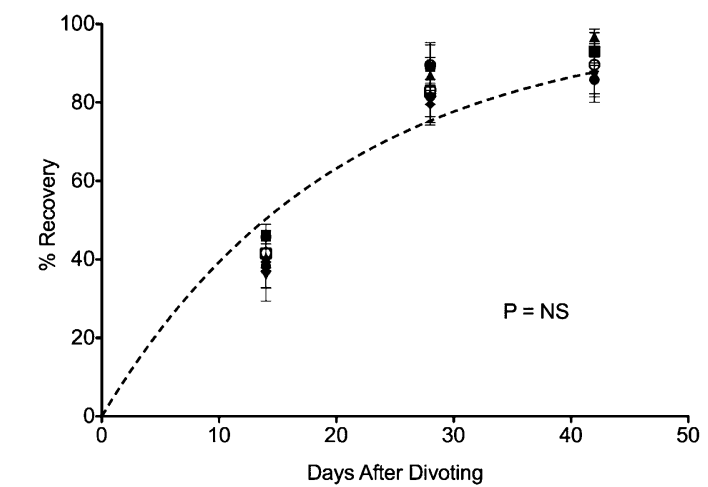

- Dithiopyr $(0.56 \mathrm{~kg})$

- Oxadiazon $(3.36 \mathrm{~kg})$

A Indaziflam (35 g)

- Indaziflam $(52.5 \mathrm{~g})$

o Pendimethalin $(3.36 \mathrm{~kg})$
口 Prodiamine $(840 \mathrm{~g})$

\section{2}

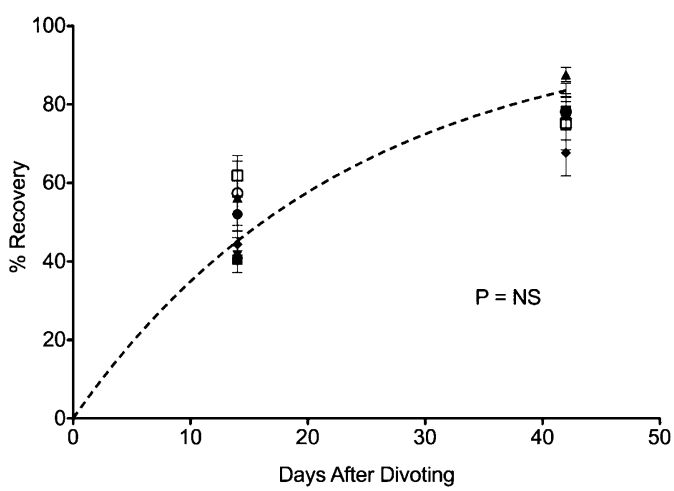

- Dithiopyr $(0.56 \mathrm{~kg})$

- Oxadiazon (3.36 kg)

○ Pendimethalin $(3.36 \mathrm{~kg})$
- Indaziflam (35 g)

v Indaziflam $(52.5 \mathrm{~g})$

口 Prodiamine $(840 \mathrm{~g})$
- Non-treated Control

\section{3}

Fig. 2. Non-linear regression models for predicting hybrid bermudagrass [C. dactylon (L.) Pers. $\times$ C. transvaalensis Burtt-Davey, cv. Tifway] recovery from divoting 1,2, and 3 months after applying seven preemergence herbicide treatments (MAT) at the University of Tennessee Center for Athletic Field Safety (Knoxville, TN) in 2012 and 2013. Vertical bars represent SE estimates. A global sum-of-squares F-test indicated that all herbicide treatments shared similar K values at each divot timing $\alpha=0.05$. 
Table 3. Non-linear regression parameters for hybrid bermudagrass [C. dactylon (L.) Pers. $\times C$. transvaalensis Burtt-Davey, cv. Tifway] divot recovery data at the University of Tennessee Center for Athletic Field Safety (Knoxville, TN) during 2012 and 2013. ${ }^{\mathrm{z}}$

\begin{tabular}{lccccccc}
\hline & \multicolumn{3}{c}{2012} & & \multicolumn{2}{c}{2013} \\
\cline { 2 - 4 } \cline { 6 - 8 } Divot Timing & $\mathrm{K}^{\mathrm{y}}$ & $\mathrm{SE}$ & $R^{2}$ & & $\mathrm{~K}$ & $\mathrm{SE}$ & $R^{2}$ \\
\hline 1 MAT & 0.019 & \pm 0.0009 & 0.67 & & 0.035 & \pm 0.0012 & 0.83 \\
2 MAT & 0.026 & \pm 0.0010 & 0.78 & & 0.043 & \pm 0.0022 & 0.64 \\
3 MAT & 0.049 & \pm 0.0021 & 0.75 & 0.043 & \pm 0.0022 & 0.50 \\
\hline
\end{tabular}

zParameters were derived from recovery data collected sgyrt divots being generated 1, 2, or 3 months after application of seven herbicide treatments. A global sum-of-squares F-test indicated that all herbicide treatments shared similar $\mathrm{K}$ values at each divot timing.

${ }^{\mathrm{y}} \mathrm{K}$ values determine recovery rate according to the formula: \%recovery $=[1-\exp (-\mathrm{K} * \mathrm{DAI})]$ where DAI $=$ days after divot injury similar to Karcher et al. (2005). Higher $\mathrm{K}$ values indicate faster recovery from divoting.

herbicides were active in soil during simulated traffic because smooth crabgrass (Digitaria ischaemum) was controlled $95 \%$ to $99 \%$ compared with the untreated control by 5 MAT. Unlike traffic stress, divoting involves the physical removal of turf and soil from the surface. This displacement may remove applied herbicide from the soil surface, therefore allowing divot recovery through stolon growth. However, herbicide concentrations in soil were not measured in this study. Future research should address this in further detail, because herbicide removal through divoting could compromise weed control efficacy.

Under the conditions of this study, applications of PRE herbicides did not affect divot resistance or recovery. However, future research should also evaluate effects of divoting on weed control efficacy of PRE herbicide applications.

\section{Literature Cited}

Beard, J. B., and H. J. Beard. 2005. Beard's turfgrass encyclopedia for golf courses grounds, lawns, sports fields. State Univ. Press, East Lansing, MI. p. 137.

Bingham, S.W. and J.R. Hall, III. 1985. Effects of herbicides on bermudagrass (Cynodon spp.) sprig establishment. Weed Sci. 33:253-257.

Boyd, J.W. and J.H. Baird. 1997. Herbicide effects on sprig establishment of Zoysia japonica CV. El Toro and Cynodon dactylon $\times$ C. transvaalensis cv. Midlawn. Intl. Turf. Soc. Res. J. 8:1025-1032.

Brosnan, J.T., G.K. Breeden, A.W. Thoms, and J.C. Sorochan. 2011. Preemergence herbicide efficacy under athletic field traffic. Online.
Appl. Turf. Sci. doi: 10.1094/ATS-2011-112801-BR.

Brosnan, J.T., W.E. Hart, A.W. Thoms, and J.R. Sarten. 2013. A new apparatus to evaluate turfgrass divot resistance. Intl. Turf. Res. J. 12 : 619-624.

Fagerness, M.J., F.H. Yelverton, and R.J. Cooper. 2002. Bermudagrass [Cynodon dactylon (L.) Pers.] and zoysiagrass (Zoysia japonica) establishment after preemergence herbicide applications. Weed Technol. 16:597-602.

Fishel, F.M. and G.E. Coats. 1993. Effects of commonly used turfgrass herbicides on bermudagrass (Cynodon dactylon) root growth. Weed Sci. 41:641-647.

Fry, L.R. 2004. Zoysiagrass recovery from divot injury. MS thesis, University of Arkansas, Fayetteville, AR.

Johnson, B.J. 1980. Root growth of southern turf cultivars as affected by herbicides. Weed Sci. 28:526-528

Jones, P.A., J.T. Brosnan, D.A. Kopsell, and G.K. Breeden. 2013. Soil type and rooting depth affect hybrid bermudagrass injury with preemergence herbicides. Crop Sci. 53:660-665.

Karcher, D.E. and M.D. Richardson. 2005. Batch analysis of digital images to evaluate turfgrass characteristics. Crop Sci. 45:1535-1539.

Karcher, D.E., M.D. Richardson, J.W. Landreth, and J.H. McCalla, Jr. 2005. Recovery of bermudagrass varieties from divot injury. Online. Appl. Turf. Sci. doi: 10.1094ATS-2005-011701-RS.

Lyman, G.T., C.S. Throssell, M.E. Johnson, G.A. Stacey, and C.D. Brown. 2007. Golf course profile describes turfgrass, landscape and environmental stewardship features. Appl. Turf. Sci. doi: 10.1094/ATS-2007-1107-01-RS.

McCarty, L.B. and G.L. Miller. 2002. Managing bermudagrass turf: Selection, construction, cultural practices, and pest management strategies. Ann Arbor Press, Chelsea, MI.

McCarty, L.B. and J.S. Weinbrecht. 1997. Cynodon dactylon $\times C$. transvaalensis Tifway sprigging establishment and weed control following pre-emergence herbicide use. Intl. Turf. Soc. Res. J. 8:507-515.

McNitt, A.S. and P.J. Landschoot. 2005. The effects of soil reinforcing materials on the traction and divot resistance of a sand root zone. Intl. Turfgrass Soc. Res. J. 10:11151122.

Motulsky, H.J. and A. Christopoulos. 2003. Fitting models to biological data using linear and nonlinear regression: A practical guide to curvefitting. GraphPad Software, Inc., San Diego, CA.

Patton, A.J., J.M. Trappe, D.E. Karcher, and M.D. Richardson. 2010. Golf club selection and golfer influence divot size in bermudagrass fairways. Arkansas Turfgrass Report 2009. Ark. Ag. Exp. Stn. Res. Ser. 579:165168.

Senseman, S.A. (ed.). 2007. Herbicide handbook. Weed Science Society of America, Lawrence, KS.

Serensits, T.J. 2008. The effects of trinexapac-ethyl and cultivation on the divot resistance of kentucky bluegrass cultivars. MS thesis, Penn State Univ. University, University Park, PA.

Sharpe, S.S., R. Dickens, and D.L. Turner. 1989. Herbicide effects on tensile strength and rooting of bermudagrass (Cynodon dactylon) sod. Weed Technol. 3:353-357.

Steinke, K. and J.C. Stier. 2003. Nitrogen selection and growth regulator applications for improving shaded turf performance. Crop Sci. 43: 1399-1406.

Thoms, A.W., J.C. Sorochan, J.T. Brosnan, and T.J. Samples. 2011. Perennial ryegrass (Lolium perenne L.) and grooming affect bermudagrass traffic tolerance. Crop Sci. 51:2204-2211.

Tillman, P.H. and J.B. Beard. 1997. The effects of six pre-emergence herbicides on the root growth of two warm-season turfgrasses. Intl. Turf. Soc. Res. J. 8:1059-1068.

Trappe, J.M., D.E. Karcher, M.J. Richardson, and A.J. Patton. 2011. Divot resistance varies among bermudagrass and zoysiagrass cultivars. Crop Sci. 51:1793-1799.

U.S. Golf Association. 2007. United States Golf Association recommendations for a method of putting green construction. 4 Jan. 2013. <http:// www.usga.org/course_care/articles/construction/ greens/Green-Section-Recommendations-For-AMethod-Of-Putting-Green-Construction/>. 